M. Klimczuk-Kochańska, A. Klimczuk, New Technology: Risks and Gains, [in:] M. Odekon (ed.), The SAGE Encyclopedia of World Poverty, 2nd Edition, SAGE Publications, Thousand Oaks 2015, pp. 1144-1147. https://doi.org/10.4135/9781483345727.n603

\title{
New Technology: Risks and Gains
}

New technologies are often radical innovations that change current activities across different areas of social and economic life. At the beginning of the 21 st century, some of these technologies are information and communications technology (ICT), nanotechnology, biotechnology, robotics, and artificial intelligence. These innovations stimulate new opportunities for the production, distribution, and consumption of goods and services, and thus can help solve social problems. But they also cause new social risks and inequalities. On the one hand, applying new technologies can bring welfare as part of a "third Industrial Revolution"; on the other hand, new technologies can cause the "future shock" of stress, disorientation, and inability to change. Examples of some of these potentially disorientations are Moore's Law on doubling computer capabilities approximately every two years, which influences almost all industries and tasks, including replacement of humans' mental work; new ICT applications that change access to health and education facilities, promote participation in governance, open access to science, and create new employment opportunities; and a transition from the digital divide to the robotics divide, with a redefinition of human lives by not only access to new technologies and data but also by the use of live improvements in everyday life, genetic enhancements, and eventually cyborgs.

Diffusion of innovations is divided by categories of adopters that reflect social inequalities. First are innovators who introduce technology to society, are entrepreneurs willing to take risks, are from the highest social class, and have sufficient resources. Second, are early adopters characterized by cosmopolitanism; they spread ideas as opinion leaders in local communities. Third are early-majority adopters, who have contact with early adopters, are slow to use new technologies, and have above-average social status and financial resources. In the fourth category are late-majority adopters, with a high degree of skepticism, below-average social status, few financial resources, and little opinion leadership. The slowest adopters are laggards who have an aversion to change agents, focus on traditions, and have the lowest social status and fewest financial resources.

\section{Gains From New Technologies}

Emerging technologies influence poverty reduction by opening new perspectives to business and labor, meeting the needs, and improving the competitiveness of countries and their communities. Examples include the use of natural resources from poor countries that were not required earlier; development of a leisure and creative class in rich societies, who have more 
M. Klimczuk-Kochańska, A. Klimczuk, New Technology: Risks and Gains, [in:] M. Odekon (ed.), The SAGE Encyclopedia of World Poverty, 2nd Edition, SAGE Publications, Thousand Oaks 2015, pp. 1144-1147. https://doi.org/10.4135/9781483345727.n603

cultural needs and are willing to invest in foreign tourism and creative industries; the invention of new technologies to challenge hunger, disease, epidemics, and depletion of natural resources; and the dissemination of open access and open source - a global democratization of access to scientific knowledge, computer applications, and industrial designs.

The possibility that new technology will transfer to developing countries is affected by numerous factors, such as the small size of the market, the shortage of raw materials, the lack of skilled labor, and adequate infrastructure. Therefore, the vast majority of technologies must be modified and adapted for use in developing nations, although in some cases, a particular technology may not be appropriate for these societies. Transfer to a developing country usually requires several modifications: (1) simplifying the technology so that it can meet the demands of a new market, particularly the reduced capacity or minimal consequences associated with lower product quality and poor economic performance; (2) redesigning the technology so that it can be used with reduced amounts of resources adequate to the new environment; and (3) providing opportunities to exploit the technology and its implementation at the level of skill that is available or can be obtained in a new environment.

ICT services are seen as especially favorable for poorer countries as they can accelerate the transformation of these nations into post-industrial societies. Examples include solutions promoted by social entrepreneurship and corporate social responsibility movements such as online volunteering, telecenters, fab labs, crowdfunding, and crisis mapping. The appropriate regulatory framework and infrastructure expansion are needed, including intellectual property rights, security, privacy, and data protection for teletrade within and between countries. More benefits of new technologies are possible by fostering developing countries' willingness to consider technology as a universal heritage and by responding to their demands for change in the legal environment that controls transfer and diffusion.

\section{Risks of New Technologies}

Critics of technological progress denounce its negative side effects. For example, critics maintain that the benefits of a knowledge-based economy are mainly concentrated in the countries of the Global North; new technologies expand the integration of stronger economies while marginalizing weaker ones; technologies create environmental pollution and decrease ecological agriculture technologies; poor countries suffer from ICT exclusion, the digital divide, and the robotics divide; technologies create new types of underclass people; and technologies result in the risks caused by piracy of intellectual property. 
M. Klimczuk-Kochańska, A. Klimczuk, New Technology: Risks and Gains, [in:] M. Odekon (ed.), The SAGE Encyclopedia of World Poverty, 2nd Edition, SAGE Publications, Thousand Oaks 2015, pp. 1144-1147. https://doi.org/10.4135/9781483345727.n603

New technologies are also generating social risks due to previously unknown and complex failure mechanisms. "Risk societies" are based on global systems that use interrelated technologies such as ICT in the stock market, nuclear energy, and transportation. Risk in technology is heterogeneous, difficult, and complex to analyze because it is embedded in social and economic contexts. Social risks are usually defined as the occurrence of random events that stimulate the use of social security mechanisms, such as old age, work accidents, divorce or sudden death of a partner, illness, or loss of a job.

New social risks were defined at the end of the 20th century as the risks people faced because of economic and social changes that are part of the transition to post-industrial societies. Most important are processes related to labor markets, such as technological unemployment and education mismatch. These risks are new and different because of their unequal distribution, resulting in a concentration of poverty among young households and single mothers. This change of social risks is stimulating the need to adjust and restructure welfare state institutions.

Magdalena Klimczuk-Kochańska

Stanislaw Staszic College of Public Administration

Andrzej Klimczuk

Warsaw School of Economics

See Also: Economic Growth and Technology; Education and Training, Technical and Vocational; Information and Communication Technology; Technology and Poverty Alleviation; Technology Divide.

\section{Further Readings}

Anderson, Stuart, and Massimo Felici. Emerging Technological Risk: Underpinning the Risk of Technology Innovation. New York: Springer, 2012.

Blakney, Michael. "Transfer of Technology and Developing Nations." Fordham International Law Journal, v.11/4 (1987).

Brynjolfsson, Erik, and Andrew McAfee. Race Against the Machine. Lexington, MA: Digital Frontier Press, 2011.

Friis, Jan Kyrre Berg Olsen, Stig A. Pedersen, and Vincent F. Hendricks, eds. A Companion 
M. Klimczuk-Kochańska, A. Klimczuk, New Technology: Risks and Gains, [in:] M. Odekon (ed.), The SAGE Encyclopedia of World Poverty, 2nd Edition, SAGE Publications, Thousand Oaks 2015, pp. 1144-1147. https://doi.org/10.4135/9781483345727.n603

to the Philosophy of Technology. Malden MA: Wiley-Blackwell, 2013.

López Pelaez, Antonio, ed. The Robotics Divide: A New Frontier in the 21st century?

London: Springer, 2014.

Quibria, M.G., Ted Tschang, and Mari-Len Reyes-Macasaquit. "New Information and Communication Technologies and Poverty: Some Evidence From Developing Asia.” Journal of the Asia Pacific Economy, v. 7/3 (2002).

Rifkin, Jeremy. The Third Industrial Revolution: How Lateral Power Is Transforming

Energy, the Economy, and the World. New York: Palgrave Macmillan, 2011.

Rogers, Everett M. Diffusion of Innovations. New York: Free Press of Glencoe, 1962.

Taylor-Gooby, Peter, ed. New Risks, New Welfare. New York: Oxford University Press, 2004.

Toffler, Alvin. Future Shock. New York: Random House, 1970. 